Journal of Organometallic Chemistry, 164 (1979) 371-380

(C) Elsevier Sequoia S.A., Lausanne - Printed in The Netherlands

\title{
SMALL RING METALLOCYCLES
}

\author{
V*. CRYSTAL AND MOLECULAR STRUCTURE OF \\ HYDRIDO-1,3-(1,1,3,3-TETRAMETHYLDISILOXANEDIYL)- \\ CARBONYLBIS(TRIPHENYLPHOSPHINE)IRIDIUM(III), \\ $\mathrm{Me}_{2} \mathrm{SiOSiMe}_{2} \mathrm{Ir}(\mathrm{H})(\mathrm{CO})\left(\mathrm{PPh}_{3}\right)_{2} \cdot \mathrm{EtOH}$
}

M. DAVID CURTIS *, JOHN GREENE and WILLIAM M. BUTLER

Department of Chemistry, The University of Michigan, Ann Arbor, Michigan 48109 (U.S.A.) (Received June 6th, 1978)

\section{Summary}

The structure of the cyclo-metalladisiloxane, $\mathrm{Me}_{2} \mathrm{SiOSiMe}_{2} \mathrm{Ir}(\mathrm{H})(\mathrm{CO})\left(\mathrm{PPh}_{3}\right)_{2}$, has been determined by single crystal $\mathrm{X}$-ray diffraction using $\mathrm{Mo}-K_{\alpha}$ radiation. Data were collected to $2 \theta=45^{\circ}$ giving 6060 unique reflections, of which $4582 \mathrm{had} I \geqslant 3 \sigma(I)$. The latter were used in the full-matrix refinement. Crystallographic data: space group, $P \bar{I}$; cell constants: $12.604(7), 12.470(4)$, 15.821(6) $\AA, 66.93(6)^{\circ}, 105.34(7)^{\circ}, 112.41(8)^{\circ} ; V 2095(3) \AA^{3} ; \rho(o b s) 1.45$ $\mathrm{g} / \mathrm{cm}^{3} ; \rho$ (calc) $1.46 \mathrm{~g} / \mathrm{cm}^{3}(Z=2)$. The asymmetric unit consists of one iridium complex and one molecule of ethanol of solvation. The structure was solved by standard heavy atom methods and refined with all non-hydrogen atoms anisotropic to final $R$ factors, $R_{1} 0.034$ and $R_{2} 0.042$. The iridium metallocycle has approximate $C_{s}$ symmetry with the mirror plane passing through the four-membered IrSiOSi ring. The average $\mathrm{Ir}-\mathrm{P}, \mathrm{Ir}-\mathrm{Si}$ and $\mathrm{Si}-\mathrm{O}$ bond lengths are $2.38,2.41$, and $1.68 \AA$, respectively. The Ir- $\mathrm{CO}$ and $\mathrm{C}-\mathrm{O}$ bond lengths are $1.903(8)$ and $1.133(8)$. The $\mathrm{H}$ atom bonded to $\mathrm{Ir}$ was not located. The Ir atom is raised out of the basal, $\mathrm{P}_{2} \mathrm{Si}_{2}$ plane toward the carbonyl by about $0.26 \AA$. The most striking feature of the structure is the strain apparen in the four-membered ring. The internal angles are: 64.7 ( $\mathrm{Si}-\mathrm{Ir}-\mathrm{Si}), 96.8(\mathrm{Ir}-\mathrm{Si}-\mathrm{O})$, $97.8(\mathrm{Ir}-\mathrm{Si}-\mathrm{O}$ ), and $99.8(\mathrm{Si}-\mathrm{O}-\mathrm{Si})$. In an unstrained molecule, the $\mathrm{Si}-\mathrm{O}-\mathrm{Si}$ angle is normally in the $130-150^{\circ}$ range. It is proposed that the strain in the ring is consistent with the catalytic activity of the metallocycle.

\section{Introduction}

Cyclo-metalladisiloxanes (I) have been found to catalyze the disproportionation of tetramethyldisiloxane (TMDS) into dimethylsilane and higher poly-

* For Part IV see ref. 17. 
siloxanes (eq. 1) $[1,2]$. The mechanism proposed for the catalysis involves the

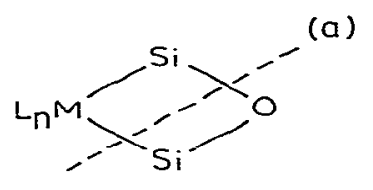

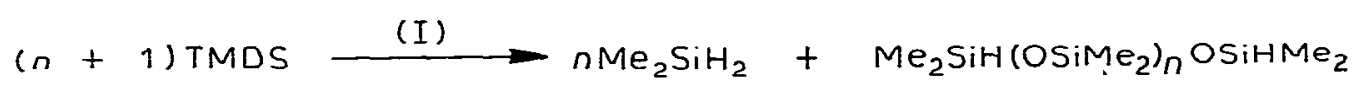

scission of the four-membered metallocycle along line a in structure $I$ to give a coordinated silylene and a silaketone $(-\mathrm{Si}=\mathrm{O})$. Since there are no reported structures of complexes containing the four-membered cyclo-metalladisiloxane ring, we have determined the structure of a representative complex, hydrido1,3-(1,1,3,3-tetramethyldisiloxanediyl)carbonylbis(triphenylphosphine)iridium(III), to determine if the catalytic activity of the complex has an identifiable, structural basis.

\section{Experimental}

Crystals of the iridium complex, prepared from TMDS and Vaska's Complex $[1,2]$, and grown from methylene chloride/ethanol solutions, were shown by axial rotation photos and counter data to be triclinic. The density indicates $Z=2$, suggesting space group $P \overline{\mathbf{I}}\left(C_{i}^{1}\right.$ No. 2$)$. This space group assignment was confirmed by the successful refinement. The density also suggests two molecules of ethanol of solvation per unit cell, and the solvate molecules were successfully located and refined. A summary of crystal and intensity collection data is given in Table 1. Cell constants were determined from a least-squares fit of 15 accurately centered reflections with $20^{\circ}<20<25^{\circ}$. Intensities of the three standards were measured after every 50 reflections and showed no significant changes during data collection.

TABLE 1

SUMMARY OF CRYSTAL AND COLLECTION DATA

\begin{tabular}{|c|c|}
\hline$a, b, c(\AA)$ & $12.064(7), 12.470(4), 15.821(6)$ \\
\hline $\begin{array}{l}\alpha, \beta, \gamma\left({ }^{\circ}\right) \\
v\left(\mathrm{~cm}^{3}\right), z\end{array}$ & $\begin{array}{l}66.93(6), 105.34(7), 112.41(8) \\
2095(3), 2\end{array}$ \\
\hline$\rho$ (obs.), $\rho$ (calc.) $\left(\mathrm{s} / \mathrm{cm}^{3}\right)$ & 1.45 .1 .46 \\
\hline Crystal dimensions (mm) & $0.31,0.21 .0 .36$ \\
\hline Radiation & Mo- $K_{\infty}$ monochromatized from a graphite crystal \\
\hline Take-off angle $\left(^{\circ}\right)$ & 4 \\
\hline$\mu\left(\mathrm{Mo}_{0}-\mathrm{K}_{\alpha}\right)\left(\mathrm{cm}^{-1}\right)$ & 35.38 \\
\hline Transmission factors & $0.52-0.38$ \\
\hline Scan speed (deg./min) & $2.0-15$ as a function of peak intensity \\
\hline Std. reflections & $04 \overline{4}, 063,5 \overline{6} \overline{2}$ \\
\hline 20 limit $\left({ }^{\circ}\right)$ & 45 \\
\hline Reflections collected & 6060 \\
\hline Reflections with $I>3 \sigma(I)$ & 4582 \\
\hline$\left[\Sigma w\left(\left|F_{\mathrm{o}}\right|-\left|F_{\mathrm{c}}\right|\right)^{2} /(N O-N V)\right]^{1 / 2}$ & 1.100 \\
\hline
\end{tabular}


During data reduction, standard deviations were assigned as follows:

$\sigma(I)=\left[\sigma_{\mathrm{c}}^{2}+P^{2} I^{2}\right]^{1 / 2}(P=0.04)$

$\sigma_{\mathrm{c}}^{-}=\left(I+K^{2} B\right)^{1 / 2}$ where $B=$ total background counts, $K=$ ratio of scan time to background time.

$\sigma\left(I^{\prime}\right)=\sigma(I) / L P, I^{\prime}=I / L P$

$\sigma(F)=\left(I^{\prime}+\sigma\left(I^{\prime}\right)\right)^{1 / 2}-\left(I^{\prime}\right)^{1 / 2}$

$w=1 / \sigma^{2}(F)$

The function minimized during refinement was $\Sigma w\left(\left|F_{0}\right|-\left|F_{\mathrm{c}}\right|\right)^{2}$. Scattering factors for non-hydrogen atoms were taken from Cromer and Waber [3]; those for hydrogen and the anomalous dispersion terms for Ir from the International Tables [4].

Computations were done on an Amdahl 470. Programs used during structure analysis were: SYNCOR (data reduction by W. Schmonsees), FORDAP (Fourier synthesis by A. Zalkin), ORFFLS (least-squares by Busing, Martin and Levy), ORFFE (distances, angles, and ESD's by Busing, Martin and Levy), ORTEP (thermal ell:psoid drawings by C.K. Johnson), HATOMS (hydrogen atom positions by A. Zalkin), PLANES (least-squares planes by D.M. Blow), and ABSORB (absorpticn correction by Templeton and Templeton using the algorithim of DeLauny and Tompa). $R_{1}=\Sigma\left(\left|F_{0}\right|-\left|F_{\mathrm{c}}\right|\right) / \Sigma\left|F_{0}\right| ; R_{2}=\left\{\Sigma\left(\left|F_{0}\right|-\left|F_{\mathrm{c}}\right|\right)^{2} \mid\right.$ $\left.\sum w\left|F_{0}\right|^{2}\right\}^{1 / 2}$.

The structure was solved by conventional heavy atom methe 's. The Ir position, located from the Patterson map, was used to phase a Fourier synthesis, from which the positions of all atoms except those in the phenyl rings and solvate could be located. These atom positions were refined once $\left(R_{1}=0.28\right)$ and a second difference map revealed all non-hydrogen atom positions. Two cycles of isotropic refinement converged at $R_{1}=0.078$ and $R_{2}=0.106$. A difference map at this stage revealed the ethanol solvate. Atom positions for the phenyl-hydrogens were calculated by taking a $\mathrm{C}-\mathrm{H}$ bond length of $1.0 \AA$ and assuming the $\mathrm{H}$ atom to lie on the $\mathrm{C}-\mathrm{C}-\mathrm{C}$ angle bisector. Fixed isotropic temperature factors were assigned to the $\mathrm{H}$ atoms with a value one unit higher than that of the contiguous carbon. These $\mathrm{H}$ atom positions and temperature factors were then included in the atom list but not refined. Continued refinement with all atoms (except $\mathrm{H}$ ) anisotropic converged at $R_{1}=0.034, R_{2}=0.042$. In the final difference map, no peak greater than $0.56 \mathrm{e} / \AA^{3}$ was observed except for two Ir residues of 1.79 and $1.61 \mathrm{e} / \AA^{3}$. The hydrogen atoms on the Si-methyls were evident, but they were not refined because of their small contribution to the structure and the already large number of variables. The number of variables was 460 , giving a data/variable ratio of 9.9/1. A statistical correlation of $R_{1}$ and $R_{2}$ with various parameters, e.g. $(\sin \theta / \lambda)^{3},\left\{F_{\mathrm{o}} \mid\right.$, and the parity of the indices, showed no significant trends.

\section{Results}

The asymmetric unit consists of one molecule of iridium complex located near the origin and one molecule of ethanol located near the inversion center at 
TABLE 2

FRACTIONAE CELL COORDINATES

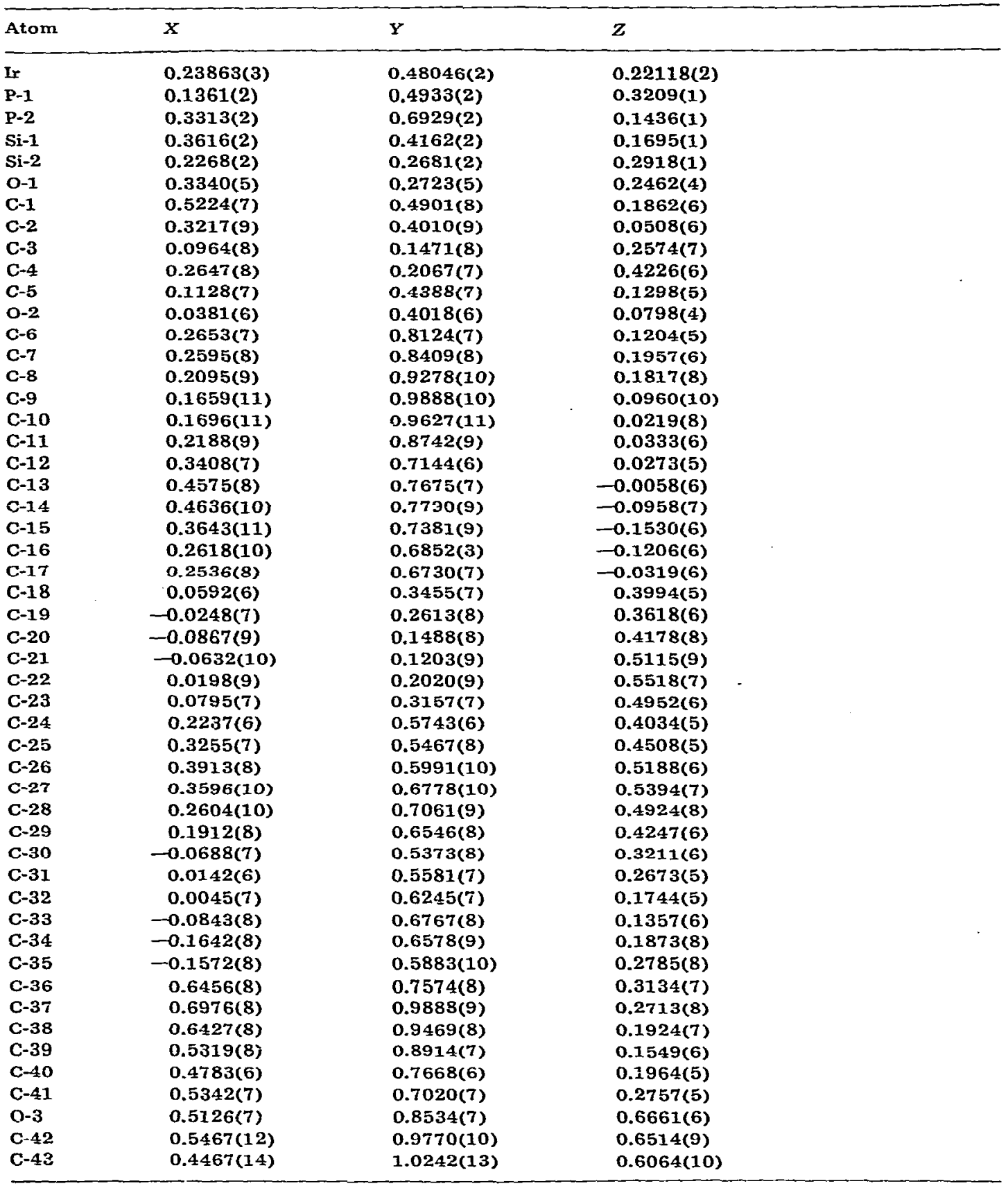


TABLE 3

ANISOTROPIC TEMPERATURE FACTORS ${ }^{a}$

\begin{tabular}{|c|c|c|c|c|c|c|}
\hline Atom & $\beta_{11}$ & $\beta_{22}$ & $\beta_{33}$ & $\beta_{12}$ & $\beta_{13}$ & $\beta_{23}$ \\
\hline Ir & $0.00588(3)$ & $0.00714(3)$ & $0.00390(2)$ & $0.00227(2)$ & $0.00081(1)$ & $-0.00095(1)$ \\
\hline P-1 & $0.0056(2)$ & $0.0081(2)$ & $0.0042(1)$ & $0.0020(1)$ & $0.0008(1)$ & $-0.0013(1)$ \\
\hline P-2 & $0.0062(2)$ & $0.0070(2)$ & $0.0044(1)$ & $0.0021(1)$ & $0.0010(1)$ & $-0.0009(1)$ \\
\hline Si-1 & $0.0083(2)$ & $0.0090(2)$ & $0.0050(1)$ & $0.0037(2)$ & $0.0012(1)$ & $-0.0016(1)$ \\
\hline Si-2 & $0.0087(2)$ & $0.0074(2)$ & $0.0055(1)$ & $0.0028(2)$ & $0.0017(1)$ & $-0.0008(1)$ \\
\hline $0-1$ & $0.0122(6)$ & $0.0094(5)$ & $0.0076(4)$ & $0.0060(5)$ & $0.0028(4)$ & $-0.0009(3)$ \\
\hline C-1 & $0.0078(8)$ & $0.0138(10)$ & $0.0081(6)$ & $0.0042(7)$ & $0.0021(5)$ & $-0.0035(6)$ \\
\hline C-2 & $0.0142(11)$ & $0.0176(12)$ & $0.0059(5)$ & $0.0075(9)$ & $-0.0001(6)$ & $-0.0051(7)$ \\
\hline C-3 & $0.0125(10)$ & $0.0108(9)$ & $0.0082(6)$ & $0.0020(8)$ & $0.0009(6)$ & $-0.0045(6)$ \\
\hline C-4 & $0.0119(10)$ & $0.0102(9)$ & $0.0058(5)$ & $0.0042(7)$ & $0.0005(5)$ & $-0.0001(5)$ \\
\hline C-5 & $0.0090(8)$ & $0.0133(8)$ & $0.0035(4)$ & $0.0034(7)$ & $-0.0002(5)$ & $-0.0021(5)$ \\
\hline $0-2$ & $0.0105(6)$ & $0.0159(8)$ & $0.0073(4)$ & $0.0034(6)$ & $-0.0023(4)$ & $-0.0042(5)$ \\
\hline$C-6$ & $0.0076(7)$ & $0.0095(8)$ & $0.0060(5)$ & $0.0027(6)$ & $0.0016(5)$ & $-0.0018(5)$ \\
\hline $\mathrm{C}-7$ & $0.0106(9)$ & $0.0116(9)$ & $0.0069(5)$ & $0.0043(7)$ & $0.0010(5)$ & $-0.0033(6)$ \\
\hline C-8 & $0.0132(11)$ & $0.0170(12)$ & $0.0110(8)$ & $0.0077(10)$ & $0.0013(8)$ & $-0.0061(9)$ \\
\hline C-9 & $0.1078(15)$ & $0.0162(13)$ & $0.0132(11)$ & $0.0121(12)$ & $0.0022(10)$ & $-0.0021(10)$ \\
\hline C-10 & $0.0214(17)$ & $0.0190(15)$ & $0.0087(8)$ & $0.0151(14)$ & $0.0025(9)$ & $0.0005(8)$ \\
\hline C-11 & $0.0170(13)$ & $0.0148(11)$ & $0.0069(6)$ & $0.0099(10)$ & $0.0019(7)$ & $-0.0005(6)$ \\
\hline C-12 & $0.0087(8)$ & $0.0079(7)$ & $0.0048(4)$ & $0.0036(6)$ & $0.0019(5)$ & $-0.0002(4)$ \\
\hline C-13 & $0.0110(9)$ & $0.0100(8)$ & $0.0053(5)$ & $0.0043(7)$ & $0.0027(5)$ & $-0.0004(5)$ \\
\hline C-14 & $0.0143(12)$ & $0.0143(11)$ & $0.0067(6)$ & $0.0072(9)$ & $0.0044(7)$ & $0.0002(6)$ \\
\hline C-15 & $0.0192(15)$ & $0.0132(11)$ & $0.0051(5)$ & $0.0083(10)$ & $0.0030(7)$ & $-0.0007(6)$ \\
\hline$C-16$ & $0.0170(13)$ & $0.0133(10)$ & $0.0039(5)$ & $0.0053(9)$ & $0.0006(6)$ & $-0.0015(5)$ \\
\hline$C-17$ & $0.0102(9)$ & $0.0112(9)$ & $0.0053(5)$ & $0.0037(7)$ & $-0.0000(5)$ & $-0.0015(5)$ \\
\hline C-1 8 & $0.0065(7)$ & $0.0088(7)$ & $0.0055(5)$ & $0.0022(6)$ & $0.0017(4)$ & $-0.0016(5)$ \\
\hline C-19 & $0.0093(8)$ & $0.0120(9)$ & $0.0067(5)$ & $0.0017(7)$ & $0.0016(5)$ & $-0.0037(6)$ \\
\hline$C-20$ & $0.0121(11)$ & $0.0100(10)$ & $0.0104(8)$ & $-0.0002(8)$ & $0.0041(7)$ & $-0.0034(7)$ \\
\hline C-21 & $0.0152(13)$ & $0.0105(10)$ & $0.0106(9)$ & $0.0010(9)$ & $0.0069(9)$ & $0.0006(8)$ \\
\hline $\mathrm{C}-22$ & $0.0138(11)$ & $0.0125(11)$ & $0.0073(6)$ & $0.0028(9)$ & $0.0041(7)$ & $0.0002(7)$ \\
\hline C-23 & $0.0086(8)$ & $0.0111(9)$ & $0.0058(5)$ & $0.0023(7)$ & $0.0024(5)$ & $-0.0006(5)$ \\
\hline C-24 & $0.0059(7)$ & $0.0092(7)$ & $0.0044(4)$ & $0.0011(6)$ & $0.0013(4)$ & $-0.0019(4)$ \\
\hline C-25 & $0.0065(7)$ & $0.0129(9)$ & $0.0056(5)$ & $0.0018(7)$ & $0.0007(5)$ & $-0.0029(5)$ \\
\hline C-26 & $0.0100(9)$ & $0.0169(12)$ & $0.0059(5)$ & $0.0019(9)$ & $0.0002(6)$ & $-0.0041(7)$ \\
\hline C.27 & $0.0122(12)$ & $0.0178(13)$ & $0.0065(6)$ & $-0.0006(10)$ & $0.0010(7)$ & $-0.0056(7)$ \\
\hline C-28 & $0.0138(12)$ & $0.0142(11)$ & $0.0094(7)$ & $0.0012(9)$ & $0.0034(8)$ & $-0.0064(3)$ \\
\hline C-29 & $0.0109(9)$ & $0.0115(9)$ & $0.0061(5)$ & $0.0028(7)$ & $0.0016(5)$ & $-0.0035(5)$ \\
\hline C-30 & $0.0067(8)$ & $0.0155(11)$ & $0.0079(6)$ & $0.0042(7)$ & $0.0019(5)$ & $-0.0037(6)$ \\
\hline C-31 & $0.0052(6)$ & $0.0102(8)$ & $0.0060(5)$ & $0.0032(6)$ & $-0.0004(4)$ & $-0.0026(5)$ \\
\hline C-32 & $0.0073(7)$ & $0.0105(8)$ & $0.0056(5)$ & $0.0026(6)$ & $0.0008(5)$ & $-0.0013(5)$ \\
\hline C-33 & $0.0090(9)$ & $0.0148(11)$ & $0.0070(6)$ & $0.0052(8)$ & $-0.0007(6)$ & $-0.0015(6)$ \\
\hline C-34 & $0.0074(9)$ & $0.0170(12)$ & $0.0096(8)$ & $0.0059(8)$ & $0.0002(7)$ & $-0.0029(8)$ \\
\hline C-35 & $0.0069(8)$ & $0.0189(13)$ & $0.0102(7)$ & $0.0054(8)$ & $0.0023(6)$ & $-0.0041(8)$ \\
\hline C-36 & $0.0082(9)$ & $0.0123(10)$ & $0.0086(6)$ & $0.0021(8)$ & $-0.0000(6)$ & $-0.0046(6)$ \\
\hline C-37 & $0.0073(8)$ & $0.0148(12)$ & $0.0107(8)$ & $0.0017(8)$ & $-0.0002(6)$ & $-0.0071(8)$ \\
\hline C-38 & $0.0097(9)$ & $0.0097(9)$ & $0.0103(7)$ & $0.0005(7)$ & $0.0022(7)$ & $-0.0037(7)$ \\
\hline C-39 & $0.0092(9)$ & $0.0085(8)$ & $0.0079(6)$ & $0.0022(7)$ & $0.0012(6)$ & $-0.0023(5)$ \\
\hline$C-40$ & $0.0055(6)$ & $0.0083(7)$ & $0.0061(5)$ & $0.0015(5)$ & $0.0007(4)$ & $-0.0032(5)$ \\
\hline$C-41$ & $0.0083(8)$ & $0.0098(8)$ & $0.0056(5)$ & $0.0032(6)$ & $0.0004(5)$ & $-0.0020(5)$ \\
\hline $0-3$ & $0.0151(9)$ & $0.0152(10)$ & $0.0128(6)$ & $0.0070(8)$ & $-0.0008(6)$ & $-0.0067(5)$ \\
\hline C-42 & $0.0212(17)$ & $0.0102(11)$ & $0.0139(11)$ & $0.0026(11)$ & $-0.0006(11)$ & $-0.0031(9)$ \\
\hline$C-43$ & $0.0275(22)$ & $0.0263(20)$ & $0.0138(11)$ & $0.0206(19)$ & $0.0030(13)$ & $-0.0003(12)$ \\
\hline
\end{tabular}

${ }^{a}$ The form of the temperature factor is $\exp \left[-\left(h^{2} \beta_{11}+k^{2} \beta_{22}+l^{2} \beta_{33}+2\left(h k \beta_{12}+h l \beta_{13}+k l \beta_{23}\right)\right)\right]$ 
TABLE 4

CALCULATED CELL COORDINATES FOR PHENYL HYDROGEN ATOMS AND ASSIGNED TEMPERATURE FACTORS

\begin{tabular}{|c|c|c|c|c|}
\hline Atom ${ }^{a}$ & $x$ & $Y$ & $\boldsymbol{z}$ & $B$ \\
\hline H(7) & $0.2 \subseteq 5674$ & 0.796010 & 0.259315 & $\mathbf{5 . 8 5 1 3 0 9}$ \\
\hline$H(8)$ & 0.205475 & 0.944183 & 0.233249 & 8.118291 \\
\hline $\mathbf{H}(9)$ & 0.140164 & 1.058703 & 0.085640 & 9.631595 \\
\hline$H(10)$ & 0.139137 & 1.008711 & -0.043072 & 8.314005 \\
\hline$H(11)$ & 0.221071 & 0.852452 & -0.021876 & 7.573917 \\
\hline$H(13)$ & 0.531261 & 0.800253 & 0.035038 & 5.269166 \\
\hline$H(14)$ & 0.543081 & 0.820758 & -0.119607 & 6.628947 \\
\hline H(15) & 0.372986 & 0.743648 & -0.216163 & 6.952065 \\
\hline$H(16)$ & 0.194474 & 0.658805 & -0.165873 & 6.978142 \\
\hline$H(17)$ & 0.175137 & 0.634632 & -0.007395 & 5.956332 \\
\hline$H(19)$ & -0.041127 & 0.282839 & 0.291866 & 5.852615 \\
\hline$H(20)$ & -0.150899 & 0.086915 & 0.388918 & 7.147051 \\
\hline$H(2 I)$ & -0.096735 & 0.035222 & 0.552081 & 8.154302 \\
\hline$H(22)$ & 0.036889 & 0.183823 & 0.622001 & 7.387093 \\
\hline$H(23)$ & 0.140324 & 0.380367 & 0.524248 & 5.108841 \\
\hline$H(25)$ & 0.352425 & 0.489957 & 0.434598 & 5.487821 \\
\hline$H(26)$ & 0.462041 & 0.573983 & 0.557523 & 7.030155 \\
\hline$H(27)$ & 0.046620 & 0.713703 & 0.589563 & 7.688870 \\
\hline$H(28)$ & 0.242414 & 0.769053 & 0.506133 & 7.396203 \\
\hline$H(29)$ & 0.118117 & 0.675268 & 0.391640 & 5.782400 \\
\hline$H(31)$ & 0.081438 & 0.522636 & 0.296121 & 4.627458 \\
\hline$H(32)$ & 0.063461 & 0.635847 & 0.135303 & 5.435923 \\
\hline $\mathrm{H}(\mathbf{3 3})$ & -0.093072 & 0.725655 & 0.066370 & 6.268525 \\
\hline$H(34)$ & -0.229763 & 0.693665 & 0.158290 & 7.296103 \\
\hline$H(35)$ & -0.218023 & 0.576983 & 0.317734 & 7.243407 \\
\hline $\mathrm{H}(37)$ & 0.778026 & 0.917783 & 0.297505 & 6.748680 \\
\hline $\mathrm{H}(38)$ & 0.684285 & 1.036926 & 0.161287 & 6.886438 \\
\hline$H(39)$ & 0.490503 & 0.939830 & 0.097301 & 5.990002 \\
\hline$H(40)$ & 0.398838 & 0.723395 & 0.169185 & 4.362324 \\
\hline$H(4 I)$ & 0.494105 & 0.611901 & 0.307145 & 5.046452 \\
\hline
\end{tabular}

$a$ Number refers to carbon atom to which the hydrogen is bonded.

$1 / 2,0,1 / 2$. The final, non-hydrogen atom positions and temperature factors are collected in Tables 2 and 3, respectively. The calculated $\mathrm{H}$ atom positions and assigned $B$ values are in Table $4 *$ A view of the moleculc and the atom numbering scheme is in Fig. 1. Figures 2 and 3 are ORTEP drawings of the inner coordination sphere. The coordinated $\mathrm{H}$ atom occupies the vacant coordination site trans to the carbonyl. Table 5 gives the calculated bond distances and agles, and some least-squares planes are described in Table 6.

\footnotetext{
* Supplementary material: see NAPS document No. 3345 for 19 pages of supplementary material. Order from NAPS, c/o Microfiche Publications, P.O. Box 3513, Grand Central Station, New York, New York 10017. Remit in advance for each NAPS accession number. Institutions and Organizations may use purchase orders when ordering, however, there is a billing charge of $\$ 5.00$ for this service. Make checks pay able to “Microfiche Publications". Photocopies are \$5.00. Microfiche are $\$ \mathbf{3 . 0 0}$ each. Outside the United States and Canade, postage is $\mathbf{\$} 3.00$ for a photocopy and $\$ 1.00$ for a fiche.
} 


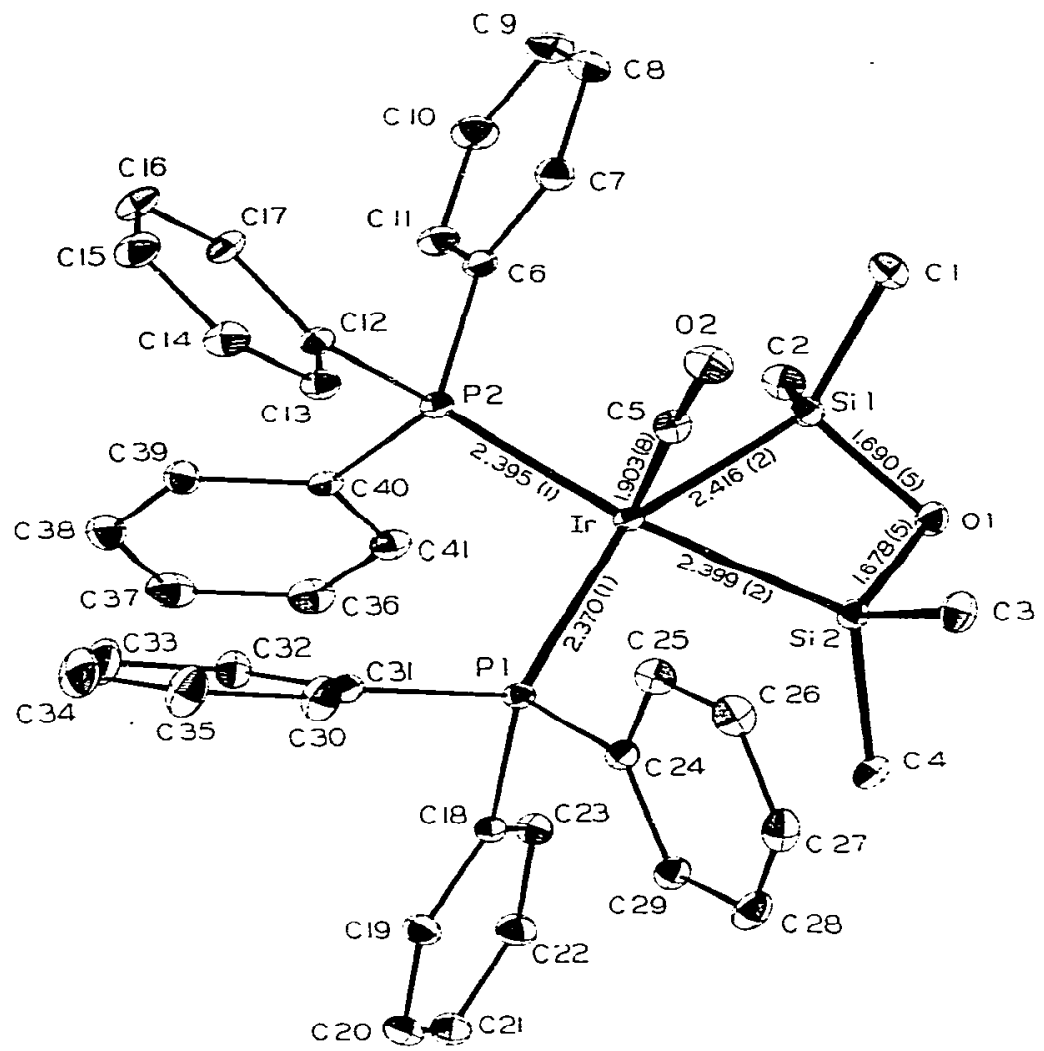

Fig. 1. ORTEP drawing of the molecule, $\left(\mathrm{Ph}_{3} \mathrm{P}\right)_{2}(\mathrm{CO})(\mathrm{H}) \operatorname{Ir}\left(\mathrm{Me}_{4} \mathrm{Si}_{2} \mathrm{O}\right)$, showing the atom numbering scheme.

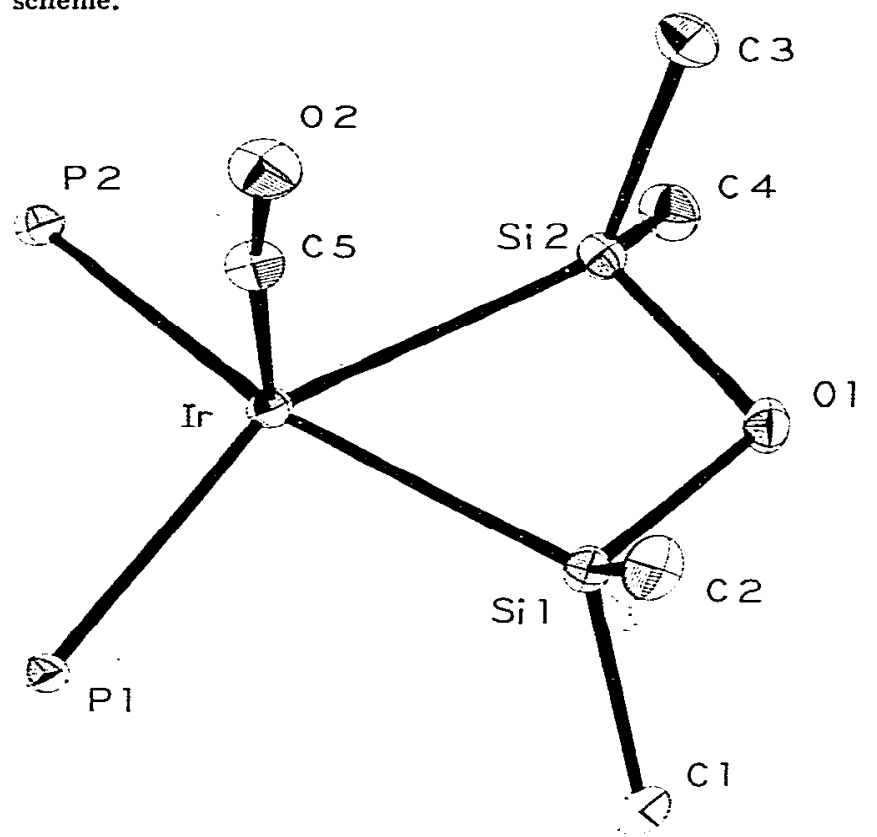

Fig. 2. ORTEP drawing of the inner coordination sphere and the IrSiOSi ring in $\left(\mathrm{Ph}_{3} \mathrm{P}\right)_{2}(\mathrm{CO})(\mathrm{H}) \mathrm{Ir}-$ $\left(\mathrm{Me}_{4} \mathrm{Si}_{2} \mathrm{O}\right)$. The hydride ligand occupies the site trans to the carbonyl. Thermal ellipsoids are at the $50 \%$ probability level. 


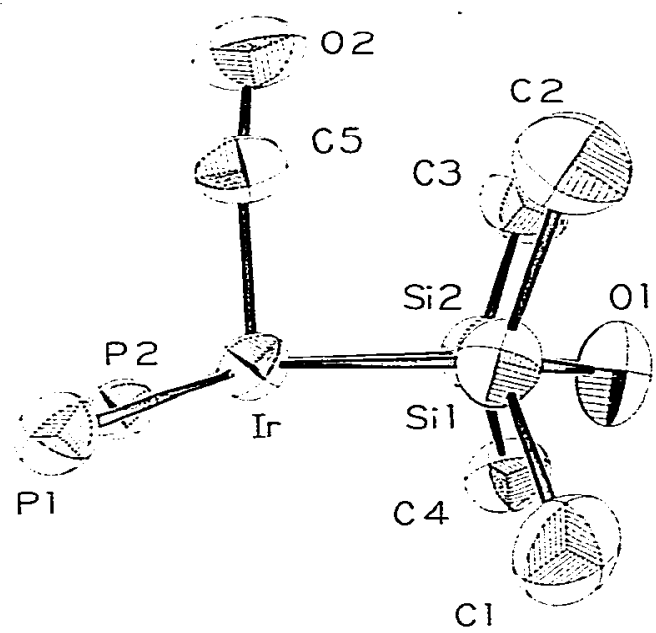

Fig. 3. ORTEP drawing of a side view of the inner coordination sphere, showing the puckering of the IrSiOSi ring and the deformation of the carbonyl, and the tilt of the Si-methyl groups away from iridium.

TABLE 5

BOND LENGTHS AND ANGLES

\begin{tabular}{|c|c|c|c|c|}
\hline Bond & Length $(\AA)$ & Bonds & Angle $\left({ }^{\circ}\right)$ & \\
\hline Ir-Si-1 & $2.416(2)$ & $\mathrm{Si}-1-\mathrm{Ir}-\mathrm{Si}-2$ & $64.70(7)$ & \\
\hline $\mathrm{Ir}-\mathrm{Si}-2$ & $2.399(3)$ & $\mathrm{Si}-1-\mathrm{Ir}-\mathrm{P}-\mathbf{1}$ & $159.97(6)$ & \\
\hline Ir-P-1 & $2.370(1)$ & Si-1-Ir-P-2 & $92.18(6)$ & \\
\hline Ir $-P-2$ & $2.395(1)$ & $\mathrm{Si}-1-\mathrm{Ir}-\mathrm{C}-5$ & $92.06(24)$ & \\
\hline $\mathrm{I} r-\mathrm{C}-5$ & $1.903(8)$ & Si-1-0-1-Si-2 & $99.80(26)$ & \\
\hline$C-5-O-5$ & $1.133(8)$ & Si-2--Ir-P-1 & $98.64(6)$ & \\
\hline $\mathrm{Si}-1-0-1$ & $1.690(5)$ & $\mathrm{Si}-2-\mathrm{Ir}-\mathrm{P}-2$ & $154.74(7)$ & \\
\hline $\mathrm{Si}-2-\mathrm{O}-1$ & $1.678(5)$ & Si-2-Ir-C-5 & $89.59(23)$ & \\
\hline Si-1-C-1 & $1.874(8)$ & P-1-Ix-P-2 & $101.54(6)$ & \\
\hline Si-1-C-2 & $1.876(8)$ & P-1-Ir-C-5 & $99.17(23)$ & - \\
\hline $\mathrm{Si}-2-\mathrm{C}-3$ & $1.890(8)$ & P-2-Ir-C-5 & $101.90(22)$ & \\
\hline $\mathrm{Si}-2-\mathrm{C}-4$ & $1.886(8)$ & Ir-Si-1-O-I & $96.81(19)$ & \\
\hline$P-1-C-18$ & $1.833(7)$ & $\mathrm{Ir}-\mathrm{Si}-1-\mathrm{C}-\mathrm{I}$ & $119.27(26)$ & \\
\hline $\mathrm{P}-1-\mathrm{C}-24$ & $1.833(7)$ & Ir $-\mathrm{Si}-1-\mathrm{C}-2$ & $118.72(30)$ & \\
\hline$P-1-C-31$ & $1.858(7)$ & Ir-Si-2-O-1 & $97.79(18)$ & \\
\hline P-2-C-6 & $1.845(7)$ & $\mathrm{Ir}-\mathrm{Si}-2-\mathrm{C}-3$ & $119.62(30)$ & \\
\hline P-2-C-12 & $1.821(7)$ & $\mathrm{Ir}-\mathrm{Si}-2-\mathrm{C}-4$ & $118.92(28)$ & \\
\hline$P-2-C-40$ & $1.861(7)$ & $0-1-S i-1-C-1$ & $106.53(34)$ & \\
\hline $\mathrm{c}-\mathrm{c}^{a}$ & $1.378 \pm 0.015$ & $\mathrm{O}-1-\mathrm{Si}-1-\mathrm{C}-2$ & $106.69(37)$ & \\
\hline \multirow{9}{*}{$\begin{array}{l}\mathrm{C}-42-\mathrm{C}-43^{\circ} \\
\mathrm{C}-42-0-3^{b}\end{array}$} & $1.485(17)$ & $\mathrm{O}-1-\mathrm{Si}-2-\mathrm{C}-3$ & $104.08(37)$ & \\
\hline & $1.371(11)$ & O-1-Si-2-C-4 & $106.57(35)$ & \\
\hline & & $C-1-S i-1-C-2$ & $106.89(42)$ & \\
\hline & & $\mathrm{C}-3-\mathrm{Si}-2-\mathrm{C}-4$ & $107.39(39)$ & \\
\hline & & $\mathrm{Ir}-\mathrm{C}-5-\mathrm{O}-2$ & $172.89(35)$ & \\
\hline & & Ir $-\mathrm{p}-\mathrm{C}^{a}$ & $116.5 \pm 3.9$ & \\
\hline & & $c-p-c^{a}$ & $101.6 \pm 2.6$ & \\
\hline & & $\mathrm{C}-\mathrm{C}-\mathrm{C}^{\mathrm{a}}$ & $120.0 \pm 1.2$ & \\
\hline & & $C-43-C-42-0-3^{b}$ & $109.10(11)$ & \\
\hline
\end{tabular}

$a$ Average value, $\sigma=\left[\Sigma(x-\bar{x})^{2} /(N-1)\right]^{1 / 2}{ }^{b}$ Ethanol of solvation: $C-43-C-42-0-3$ 
TABLE 6

DISTANCES OF ATOMS FROM SELECTED LEAST-SQUARES PLANES

\begin{tabular}{|c|c|c|c|}
\hline Plane (1) ${ }^{a}$ & Distance $^{b}$ & Plane $(2)^{a}$ & Distance $^{b}$ \\
\hline Ix & -0.212 & Ir & 0.039 \\
\hline P-1 & 0.065 & Si-1 & -0.056 \\
\hline P-2 & 0.056 & $\mathrm{Si-2}$ & -0.057 \\
\hline Si-1 & 0.047 & $0-1$ & 0.074 \\
\hline Si-2 & 0.043 & & \\
\hline
\end{tabular}

$a^{a}$ Equations defining the planes: (1) $-0.677 x-0.141 y-0.722 z+4.978=0 ;(2)-0.628 x-0.307 y-$ $0.715 z+5.622=0 .{ }^{b}$ Normal to the plane. Ir is displaced toward the carbonyl in plane (1), away from the carbonyl in plane (2).

\section{Discussion}

The structure consists of discrete molecules of metallocycle and an ethanol of solvation with only normal non-bonded distances between molecules. The closest intermolecular distance is $3.27 \AA$ between C-27 and O-3.

The coordination sphere about the iridium is distorted octahedral, and the iridium atom is displaced out of the $\mathrm{P}_{2} \mathrm{Si}_{2}$ plane some $0.26 \AA$ toward the carbonyl. The $\mathrm{P}-\mathrm{Ir}-\mathrm{P}$ angle $\left(102^{\circ}\right)$ is larger than the idealized $90^{\circ}$, but this is not unusual in complexes containing bulky phosphine ligands [5-7]. The $\mathrm{Si}-\mathrm{Ir}-\mathrm{Si}$ angle $\left(64.70(7)^{\circ}\right)$ is grossly compressed as a result of the small bite of the disiloxanediyl ligand (see below). The carbonyl group is both canted and bent to ward the siloxane ring as can be seen from the average $\mathrm{P}-\mathrm{Ir}-\mathrm{CO}$ and $\mathrm{Si}-\mathrm{Ir}-\mathrm{CO}$ angles, $100^{\circ}$ and $91^{\circ}$, respectively, and the Ir-C-O angle, $172.9(4)^{\circ}$ (see Figs. 2 and 3 ).

The Ir-Si bond distances appear to be normal. The average $\mathrm{Ir}-\mathrm{Si}$ distance $(2.41 \AA)$ is $0.03 \AA$ longer than the average $\mathrm{Ir}-\mathrm{P}$ distance $(2.38 \AA)$. The covalent radius of $\mathrm{Si}$ is some $0.04 \AA$ larger than that for $\mathrm{P}$ as judged by a variety of $\mathrm{Si}-\mathrm{X}$ and $\mathrm{P}-\mathrm{X}$ bond lengths [8].

Some of the more striking features of the structure are related to the strain present in the four-membered metallocycle. The $65^{\circ} \mathrm{Si}-\mathrm{Ir}-\mathrm{Si}$ angle is compressed $25^{\circ}$ from the ideal, octahedral $90^{\circ}$; the average $\mathrm{Ir}-\mathrm{Si}-\mathrm{O}$ angle is $97.3^{\circ}$, and the $\mathrm{Si}-\mathrm{O}-\mathrm{Si}$ angle is $99.8(3)^{\circ}$. The last angle represents a $30-50^{\circ} \mathrm{com}$ pression from the normal $130-150^{\circ}$ found for $\mathrm{Si}-\mathrm{O}-\mathrm{Si}$ angles in unstrained siloxanes [8]. The large $\mathrm{Si}-\mathrm{O}-\mathrm{Si}$ angle in siloxanes has been attributed to the effects of $(p-d) \pi$ bonding between silicon and oxygen, so that a decrease in the $\mathrm{Si}-\mathrm{O}-\mathrm{Si}$ angle suggests loss of multiple bond character in the $\mathrm{Si}-\mathrm{O}$ bond in the metallocycle. Consequently, the $\mathrm{Si}-\mathrm{O}$ bond should be weakened and lengthened. The observed SiO bond length, $1.684 \pm 0.008 \AA$, is in fact somewhat longer than $\mathrm{Si}-\mathrm{O}$ bonds in unstrained siloxanes $(\mathrm{Si}-\mathrm{O} \approx 1.63-1.65 \AA)$ [8-10]. The catalytic activity of these cyclo-metalladisiloxanes may have its origin, at least in part, in the weakening of the $\mathrm{Si}-\mathrm{O}$ bond by angle strain $[1,2]$.

The $\mathrm{Me}-\mathrm{Si}-\mathrm{Me}$ planes are also canted away from the iridium atom. I hus, the average $\mathrm{Ir}-\mathrm{Si}-\mathrm{Me}$ angle is $119.1 \pm 4^{\circ}$ and the average $\mathrm{O}-\mathrm{Si}-\mathrm{Me}$ angle is $106.0 \pm 1.3^{\circ}$. The average value of the $\mathrm{Me}-\mathrm{Si}-\mathrm{Me}$ angle is $107.1 \pm 4^{\circ}$ which is not unusual $[9,10]$. Thus, the internal strain in the four-membered ring is not 
transmitted to the external $\mathrm{C}-\mathrm{Si}-\mathrm{C}$ angles. A similar observation has been made regarding the structures of dinuclear complexes in which $\mathrm{R}_{2} \mathrm{E}(\mathrm{E}=\mathrm{Si}, \mathrm{Ge}, \mathrm{Sn})$ groups bridge metal-metal bonds and in which the $\mathbf{M}-\mathbf{E}-\mathbf{M}$ angies are extremely acute $\left(\sim 70^{\circ}\right)$ [11]. Bent $\mathrm{M}-\mathrm{E}$ bonds were postulated to explain the insensitivities of the $\mathrm{R}-\mathrm{E}-\mathrm{R}$ angle and $J\left(\mathrm{Sn}^{119}-\mathrm{CH}\right)$ coupling constants to the $\mathrm{M}-\mathrm{E}-\mathrm{M}$ angle deformations $[11,12]$. It seems likely that the Ir-Si bonds in the present structure are also "bent", i.e., the maximum electron density lies outisde the Ir-Si axis. If the two $\mathrm{Si}-\mathrm{C}$ vectors and the $\mathrm{Si}-\mathrm{O}$ vector are taken to define three vectors to the vertices of a tetrahedron about $\mathrm{Si}$, then the remaining vertex vector lies about $13^{\circ}$ off the Ir-Si axis. It may be a coincidence, but the vector from Ir to a vertex of an idealized octahedron centered on Ir also lies about $12^{\circ}$ off the Ir-Si axis. These two idealized "bond vectors" intersect about $0.3 \AA$ off the Ir $-\mathrm{Si}$ axis at a point nearly midway between $\mathrm{Ir}$ and $\mathrm{Si}$. Thus, the angles about silicon are consistent with the notion of bent bonds in strained metallocycles.

The $\mathrm{Ir}-\mathrm{Si}-\mathrm{O}-\mathrm{Si}$ ring is also folded along the $\mathrm{Si} \cdots \mathrm{Si}$ axis. The displacements of the atoms from the mean plane are given in Table 6. Such ring puckering is observed in most cyclobutanes and heterocyclobutanes [13,14], and two platinacyclobutanes also show a puckered ring $[15,16]$. Ring puckering is regarded as a mechanism for relieving non-bonded repulsions between ring substituents, but it is difficult to see any particular non-bonded interaction in the Ir-Si-O-Si ring which would favor a buckled ring over a planar one.

In conclusion, the structure of the iridia-cyclo-disiloxane has provided structural support for the proposition that ring strain weakens the $\mathrm{Si}-\mathrm{O}$ bond, and that the relief of strain by ring scission may be the driving force for the chemical reactions responsible for the catalytic activity of these metallocycles [2].

\section{Acknowledgement}

The authors thank the National Science Foundation for the support through Grant CHE77-01577.

\section{References}

1 J. Greene and M.D. Curtis, J. Amer. Chem. Soc., 99 (1977) 5176.

2 M.D. Curtis and J. Greene, J. Amer. Chem. Soc., 100 (1978) 6362.

3 D.T. Cromer and J.T. Waber, Acta Crystallogr., 18 (1965) 104.

4 C.H. Macgillavry, G.D. Reich and K. Londsale (Eds.), International Tables for X-ray Crystallography, Vol. III, Kynoch Press, Birmingham, 1962.

5 M. Cowie, B.L. Haymore and J.A. Ibers, J. Amer. Chem. Soc., 98 (1976) 7608.

6 J.S. Ricci and J.A. Ibers, J. Amer. Chem. Soc., 93 (1971) 2391.

7 F.W.B. Einstein, A.B. Gilchrist, G.W. Rayner-Canham and D. Sutton. J. Amer. Chem. Soc., 93 (1971) 1826.

8 A.F. Wells, Structural Inorganic Chemistry, Ciarendon Press, Oxford, 3rd ed., 1962.

9 V.E. Shklover, A.E. Kalinin, A.I. Gusev, N.G. Bokii, Yu.T. Struchkov, K.A. Andrianov and I.M. Petrova, Zh. Strukt. Khim., 14 (1973) 629.

10 V.E. Shklover, N.G. Bolii, Yu.T. Struchkov, K.A. Anrianov, B.G. Zavin and V.S. Suistunov, Zh. 3trukt. Khim., 15 (1974) 90.

11 K. Triplett and M.D. Curtis, J. Amer. Chem. Soc., 97 (1975) 5747.

12 K. Triplett and M.D. Curtis, Inorg. Chem., 15 (1976) 431.

13 J. Laane, Quart. Revs., 25 (1971) 533.

14 R.M. Moriarty in F.L. Eliel and N.L. Allinger (Eds.), Topics in stereochemistry, Vol. 8, Interscience, New York, 1974.

15 R.D. Gillard, M. Keeton, R. Mason, M.F. Pilbrow and D.R. Russell. J. Organometal. Chem., 33 (1971) 247.

16 J.A. MeGinnety, J. Organometal. Chem., 59 (1973) 429.

17 M.D. Curtis and R.J. Klingler. J. Organometal. Chem., 161 (1978) 23. 